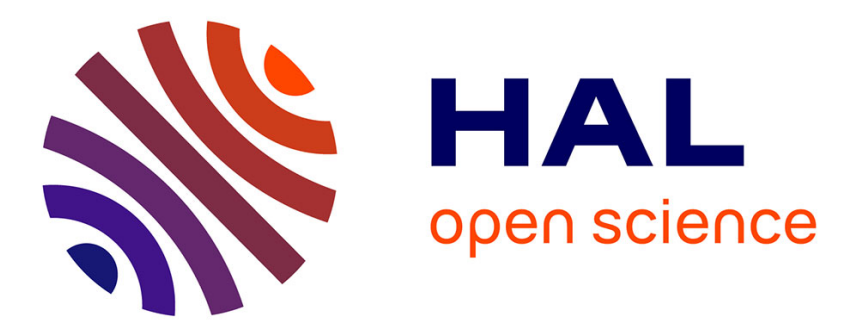

\title{
The dissolution kinetics of natural gypsum: a case study of Eocene facies in the north-eastern suburbs of Paris
} Imen Zaier, Joël Billiotte, Arnaud Charmoille, Farid Laouafa

\section{To cite this version:}

Imen Zaier, Joël Billiotte, Arnaud Charmoille, Farid Laouafa. The dissolution kinetics of natural gypsum: a case study of Eocene facies in the north-eastern suburbs of Paris. Environmental Earth Sciences, 2021, 80 (1), pp.8. 10.1007/s12665-020-09275-x . ineris-03137843

HAL Id: ineris-03137843

https://hal-ineris.archives-ouvertes.fr/ineris-03137843

Submitted on 30 Jun 2021

HAL is a multi-disciplinary open access archive for the deposit and dissemination of scientific research documents, whether they are published or not. The documents may come from teaching and research institutions in France or abroad, or from public or private research centers.
L'archive ouverte pluridisciplinaire HAL, est destinée au dépôt et à la diffusion de documents scientifiques de niveau recherche, publiés ou non, émanant des établissements d'enseignement et de recherche français ou étrangers, des laboratoires publics ou privés. 


\title{
The dissolution kinetics of natural gypsum: a case study of Eocene facies in the north-eastern suburbs of Paris
}

\author{
I. Zaier ${ }^{1,2}$. J. Billiotte ${ }^{2}$ A. Charmoille ${ }^{1}$. F. \\ Laouafa ${ }^{1}$
}

\begin{abstract}
The dissolution kinetics of different varieties of natural gypsum samples with different porosity and content of insoluble impurities are experimentally investigated under unsaturated conditions. The main goal of this work is to verify whether and how the petrophysical and petrographic nature of gypsum influence its dissolution rate. Gypsum samples were taken from Priabonian (Ludian) and Lutetian formations located in the north-eastern suburbs of Paris, where the development of sinkholes due to gypsum dissolution is a common phenomenon. Experiments using the rotating disk technique allow us to determine the kinetic rate model parameters of each sample in pure water following the empirical rate expression derived from mixed kinetic theory. The kinetic order $n$ shows a dispersion around a mean value $n=1.2$ and $k$, the pure dissolution rate coefficient varies according to the facies and the experimental conditions $\left(\mathrm{k} \approx 1 \times 10^{-6}\right.$ to $\left.8 \times 10^{-6} \mathrm{mmol} / \mathrm{cm}^{2} / \mathrm{s}\right)$. These results are adjusted according to the specific roughness and texture of each sample, for the results to be more representative of in-situ conditions. Batch experiments are also performed in order to evaluate the extremely low dissolution rates when the solution is close to equilibrium. The results reveal a double kinetics: far from equilibrium, the dissolution rates show that the linear behavior and the kinetic parameters are relatively close with the values found using the rotating disk method. For concentrations greater than $0.94 \pm 0.02$ of the equilibrium concentration $C_{r e f}$, the dissolution rates show a linear behavior but with greater slope depending on the texture of the mineral. No changes of the dissolution rates were observed on pure gypsum crystals when non soluble solid impurities are added. However, a small degree of uncertainty around the value of $C_{r e f}$ show a significant effect on the parameters of the second kinetics.
\end{abstract}

\footnotetext{
$凶$ Imen Zaier

imen.zaier@ineris.fr

imen.zaier@mines-paristech.fr

${ }^{1}$ National Institute for Industrial Environment and Risks (Ineris). Rue Jacques Taffanel, 60550 Verneuilen-Halatte.France.

${ }_{2}^{2}$ MINES ParisTech, PSL Research University, Centre de Géoscience. 35 rue Saint-Honoré, 77300

Fontainebleau.France.
} 
Keywords Dissolution kinetics · Natural gypsum · Impurity effects · Rotating disk · Batch

\section{Introduction}

Gypsum, composed of hydrated calcium sulfate $\left(\mathrm{CaSO}_{4}, 2 \mathrm{H}_{2} \mathrm{O}\right)$, is a moderately soluble mineral. Its solubility in water is $2.5 \mathrm{~g} / \mathrm{L}$ at $25^{\circ} \mathrm{C}$. Gypsum is different from most other solutes in that it reveals retrograde or inverse temperature dependent solubility behavior (Rolnick, 1954; Klimchouk, 1996; Lebedev, 2015; Dai et al., 2016). Gypsum exists in many geological formations. In our work, we focus on gypsum located under the Île-de-France district close to the center of the Paris Basin region where deposits are mainly concentrated in two Eocene formations (Egal et al., 2017): a) the "gypsum masses and interstratified marls" of Ludian (Priabonian) age (37My $34 \mathrm{My}$ ) where gypsum forms continuous stratiform "masses" about 20 meters thick $\left(1^{\text {st }}\right.$ gypsum mass layer) to less than 10 meters or about a meter thick (from the $2^{\text {nd }}$, $3^{\text {rd }}$ and $4^{\text {th }}$ gypsum mass layers), b) the "marls and loose stones" of Lutetian age (46My - 40My) where massive gypsum is present in the form of nearly regular or lenticular horizontal layers when geological layers have not undergone significant tectonic deformation, as in Vaucluse in France. Nevertheless, these deposits have often been eroded and now represent only a part of the initial formation. When geological layers have undergone a strong tectonic deformation, such as for Triassic deposits, the gypsum formations then present a very complex geometry, in the form of stretched and discontinuous layers, closely associated with other types of rocks (limestones, dolomites, shales ...) (Charmoille et al., 2018). Most of gypsum facies revolve around two distinct poles without apparent relationship: one is mainly alabaster and the other is essentially saccharoidal. However, this reduction into two groups hides a large petrographic diversity, depending on the crystal structure and grain size (Toulemont, 1987b). Apart from lenticular and rare macled crystals such as "glassy arrowhead gypsum" present in certain dolomitic levels, natural gypsum rocks are often associated with insoluble materials throughout their diagenetic and epigenetic history (Lebedev and Lekhov, 1990). This can considerably affect various gypsum properties according to the precipitation/recrystallization conditions and the insoluble residue content (Labourguigne et al., 1972; Marteau, 1993; Jaworska, 2012). Among them, the rock's texture shades (translucent, white, grey to black, yellowish to honey yellow, brown...), structure (fine-grained, coarse-grained, selenite crystals...), porosity and strength.

Gypsum has been intensively extracted for several centuries in France, particularly in Île-de-France, where it represents a major part of the resource area (PrunierLeparmentier et al., 2007). In addition to its industrial extraction, natural dissolution of gypsum occurs when in contact with groundwater flow. This is the case for example in Paris region where the dissolution of gypsum layers in the Lutetian marl and loose stones formation occur in the direction of groundwater flow (figure 1). The dissolution of gypsum rocks induces a loss of solid material creating voids with different shapes and sizes that can lead to large underground collapse or subsidence in the case of an extremely vulnerable site exposed to "brutal" hydraulic disturbances 
of hydroclimatic or anthropic origin, such as rainwater infiltration, intensive pumping from a confined aquifer or temporary drawdowns during a construction period (Toulemont, 1987a; Thierry et al., 2009; Daupley et al., 2016; Charmoille et al., 2018). The physico-chemical properties of groundwater have a direct influence on the solubility of gypsum. When in contact with natural water rich in calcium and sulphate compounds, the solubility of gypsum decreases by common ion effect (Vieillefon, 1979; Sun et al., 2015). In Paris region, most of aquifers are carbonate-calcareous $\left(\mathrm{HCO}_{3}^{-}\right.$ and $\mathrm{Ca}^{2+}$ ions). A few are sulphated-calcareous $\left(\mathrm{SO}_{4}^{2-}\right.$ and $\left.\mathrm{Ca}^{2+}\right)$ found in the Lutetian and Alluvium formations (Diffre, 1972). However, gypsum solubility increases in the presence of salts with no common ions $\left(\mathrm{Ca}^{2+}\right.$ or $\left.\mathrm{SO}_{4}^{2-}\right)$. In fact, for water with the same salinity as sea water, the solubility increases by $100 \%$ and can rise by $250 \%$ for natural brines (Klimchouk, 1996). In this context, slow and smooth deformations can be observed in the Île-de-France area but frequently, localized collapses (sinkholes) are reported in areas where the water level of the Lutetian groundwater has particularly decreased over the last century (Diffre, 1972). For instance, in areas beneath Paris, where the subsoil is rich with gypsum, one of the iconic events is the discovery of a gypsum cavity in 1975 under Paris-Nord railway station (Toulemont, 1987a) that revealed a failure migrating up through the cover rocks. It was induced by a continuous pumping of the aquifer of Eocene age for over a century. Another example can be found in urban areas around the north east suburbs of Paris (Sevran and Villepinte) where recent and numerous collapses of the ground were caused by the development of underground cavities. This indicates that, apart from major human activities such as industrial pumping and hydraulic management systems (Chardon and Nicod, 1996; Klimchouk, 1996; Gysel, 2002), dissolution mechanisms remain active in Île-de-France and they are likely to have a direct impact on the population and infrastructure.

It is therefore important to have a better knowledge on the dissolution mechanisms in the regions of gypsum occurrence and to quantify the key parameters involved in the water-gypsum interaction. Classical experimental methods used to determine dissolution kinetics parameters focus on the concentration of the dissolved species produced in solution from the combined effect of both diffusion and convection using experiments under well-controlled flow conditions such as rotating disk setups or flow cell devices (Barton and Wilde, 1971; Liu and Nancollas, 1971; James and Lupton, 1978; Jeschke et al., 2001; Wang et al., 2010; Lebedev, 2015; Dai et al., 2016). More recent experiments focus on characterizing kinetic processes at a nanometric scale by measuring atomic force (Dove and Platt, 1996; Burgos-Cara et al., 2016; Zareeipolgardan et al., 2017) or holographic interferometry (Colombani and Bert, 2007). In these previous studies, gypsum samples used are often as form of powders, polished or cleaved crystals or selenite and the solvent used is often pure water so that there is no effect on the solubility and texture of gypsum samples (Vieillefon, 1979; Klimchouk, 1996). The global results agree fairly well (Colombani, 2012) but the effect of insoluble particles in natural gypsum on the dissolution kinetics is often neglected (Sadeghiamirshahidi and Vitton, 2018). Thus, there is still currently a high uncertainty regarding the dissolution mechanisms of natural gypsum and the hydrodynamic, chemical and mechanical conditions involved in this process. 
This paper describes the experiments employed for investigating the dissolution rates of different varieties of natural gypsum under unsaturated solution conditions. The parameters of the dissolution kinetics of each sample tested are first determined at 15 and $20^{\circ} \mathrm{C}$ using the rotating disk method. These results are then adjusted according to the surface roughness acquired by the sample during dissolution. Solubility analysis are also performed to evaluate the saturation state of the solution since the rotating disk experiment shows poor accuracy of the measurements when the solution is close to equilibrium. Finally, batch reactor experiments are carried out to characterize the dissolution rates of these samples close to the saturation state of the solution.

The collected data from this work will be a key input to the numerical approaches (Luo et al., 2014; Guo, 2015; Guo et al., 2016) developed to model dissolution problems.

\section{Basic definitions}

The dissolution rate $\tau$ is a parameter that characterizes the dissolution kinetics. It expresses the amount of mass dissolved into solution per unit of time and surface under standardized conditions of solvent and mineral composition, temperature and liquid/solid interface (Beyssac and Lavigne, 2005). Its SI unit is $\mathrm{mol} / \mathrm{m}^{2} / \mathrm{s}^{-1}$ and in practice, it is expressed in $\mathrm{g} / \mathrm{m}^{2} / \mathrm{s}^{-1}$. Using the bulk density of the gypsum rock, which is written as a function of the grain density $\left(2.32 \mathrm{~g} / \mathrm{cm}^{3}\right)$ and the total porosity $\phi$, the dissolution rate could be expressed in terms of velocity $(\mathrm{m} / \mathrm{s})$. It is commonly called the recession rate, generally expressed in $\mu \mathrm{m} / \mathrm{s}$. In simple cases, i.e. rock salt, the dissolution rate $\tau$ is expressed by a first-order kinetic model (Durie and Jessen, 1964; Liu and Nancollas, 1971; Alkattan et al., 1997) in the form:

$$
\tau=k\left(1-C / C_{r e f}\right)
$$

where $\mathrm{C}$ is the concentration of the dissolved mineral species $\left(\mathrm{mmol} / \mathrm{cm}^{3}\right), C_{r e f}$ the equilibrium concentration and $\mathrm{k}$ the dissolution rate coefficient of the mineral in pure water.

The dissolution of gypsum appears to be more complex and it requires a law coupling surface reactions with transport in three main steps (Rickard and Sjoeberg, 1983). First, the reaction of gypsum with undersaturated solution induces a dissociation phenomenon of calcium $(\mathrm{Ca})$ and sulphate $\left(\mathrm{SO}_{4}\right)$ ions. This kinetic model controlled by dissociation reaction was assumed, on a global scale, purely linear in some previous researches (Liu and Nancollas, 1971; Barton and Wilde, 1971; James and Lupton, 1978; Lebedev and Lekhov, 1990). However, this model does not consider the fact that dissolution can occur inside the pores and fine fissures of a gypsum massif as water flowing through fissure systems saturates after a short distance (Jeschke and Dreybrodt, 2002). Therefore, this has been corrected by considering a non-linear kinetics that allows to reproduce the evolution of extensive fissures in karst aquifers under normal hydrogeological conditions (Levich, 1962; Palmer, 1991; Dreybrodt, 1996). This kinetic model follows a power law of order $n$ :

$$
\tau_{d}=k_{s}\left(1-C_{s} / C_{r e f}\right)^{n}
$$


Where $k_{s}$ the dissolution rate coefficient in $\mathrm{mmol} / \mathrm{cm}^{2} / \mathrm{s}^{-1}, C_{s}$ the concentration of dissolved species at the surface of the mineral. Similarly, the analysis of the experimental results at the local scale also defines a non-linear kinetics, called mixed, and of order $n$ greater than 1.

Second, a transport phenomenon of the calcium and sulphate ions occurs by molecular diffusion through a diffusion boundary layer (DBL) (Lebedev, 2015). The kinetic model controlled by molecular transport is based on Fick's second law on the diffusion layer and it is expressed by Nernst-Brunner's equation (Dokoumetzidis and Macheras, 2006):

$$
\tau_{t}=k_{t}\left(C_{s}-C_{b}\right) / C_{r e f}
$$

Where $\tau_{t}$ is the diffusion rate, $C_{b}$ the concentration of dissolved species in the solution and $k_{t}=\frac{D}{\delta} C_{r e f}$ the transport coefficient function of DBL thickness $\delta$ and D the diffusion constant of the dissolved species (Barton and Wilde, 1971; Lasaga, 1998; Colombani, 2008). Finally, dissociated ions are advected by the fluid flow and contribute then to the evolution of the concentration of the solution in motion.

The dissolution coefficients $k_{s}$ and $k_{t}$ are slightly different (Jeschke et al., 2001) and the effective dissolution rate of gypsum $\tau$ is described by a mixed reactiontransport kinetic model obtained from the mass balance and continuity condition at the interface of the boundary layer:

$$
\tau_{d}=\tau_{t}
$$

A more complex dissolution kinetic model was proposed by Jeschke et al. in 2001 (Jeschke et al., 2001) from their experimental results with natural gypsum. It distinguishes two domains of relative concentration where the kinetic order of the reaction has very different $n_{1}$ and $n_{2}$ values:

$$
\begin{array}{ll}
\tau_{1}=k_{s_{1}}\left(1-C_{s} / C_{r e f}\right)^{n_{1}} & \text { for } C_{s}<0.94 C_{r e f} \\
\tau_{2}=k_{s_{2}}\left(1-C_{s} / C_{r e f}\right)^{n_{2}} & \text { for } C_{s} \geq 0.94 C_{r e f}
\end{array}
$$

For the first domain far from equilibrium, the $n_{1}$ value proposed by Jeschke et al. (Jeschke et al., 2001), ( $\left.n_{1}=1.2 \pm 0.2\right)$ is in close agreement with the values proposed in other studies (Gregory and Riddiford, 1956; Barton and Wilde, 1971; Liu and Nancollas, 1971; James and Lupton, 1978; Lebedev and Lekhov, 1990; Shiraki and Brantley, 1995; Raines and Dewers, 1997) for $C<0.9 C_{r e f}$. But close to the equilibrium, the $n_{2}$ value is very high $\left(n_{2}=4\right.$ to 4.5$)$ and it could correspond to germination kinetics. Since this transition is not observable for synthetic gypsum (Jeschke et al., 2001), this could be due to the presence of insoluble residue content that are able to form crystallization nuclei but also of the regularity of crystals as well as specific experimental conditions (very fine grain size) that could increase the precipitation rate (Wang et al., 2010). A recent study performed by Stawski (Stawski et al., 2016) showed the formation of aggregates of nano-meter scale before the crystallization of gypsum, which could modify the diffusion regime in the boundary layer and could give evidence to the nonlinear kinetic model.

Basically, values of the rate parameter and the kinetic order $n$ are obtained by fitting 
experimental measures of the solution concentration over time by using the analytical expression of the dissolution kinetic model:

$$
\tau=\frac{V}{A} \times \frac{d C}{d t}
$$

Where $V$ is the volume of the solution and $A$ the area of dissolving surface. Two experimental methods have been used:

1. The rotating disk technique maintains constant and uniform boundary conditions and it is effective for solving fluid flow equations appropriately. In fact, in the case of a well-defined plane surface of a rotating disk immersed in a solution, the diffusion boundary layer thickness $\delta$ is controlled by the angular velocity and does not depend on the disk diameter size $(\mathrm{cm})$ (Gregory and Riddiford, 1956; Levich, 1962; Barton and Wilde, 1971; Jeschke et al., 2001; Colombani, 2012). The layer thickness is given by: $\delta=1.61 D^{1 / 3} \vartheta^{1 / 6} \omega^{-1 / 2}$ with $\vartheta$ the kinematic viscosity $\left(\mathrm{cm}^{2} / \mathrm{s}\right)$ and $\omega(\mathrm{rad} / \mathrm{s})$ the angular velocity of the disk.

2. The batch experiment is more efficient in monitoring and measuring the extremely low dissolution rates when the fluid concentration is close to equilibrium. Following the experimental procedure described by Jeschke et al. (Jeschke et al., 2001), we intend to verify if there is a difference in kinetics for various gypsum facies taken from the Parisian region and to evaluate the influence of gypsum texture on dissolution rates.

\section{Case study and materials}

In this study, the quantification of dissolution rates was carried out on natural gypsum with different textures implying different contents of insoluble impurities. Studied samples were selected from cores and they are representative of the Eocene geological formation (56My - 34My), as located in the Seine-St-Denis department, about fifteen kilometers northeast of Paris. This area is characterized by a high population density, resulting in significant urbanization that generates an increase in traffic and therefore an increased demand on infrastructure. Therefore, our work should be used to predict and to prevent the gypsum dissolution and to manage underground construction projects accordingly in the concerned areas. One of the major projects in progress is the Grand Paris Express, the largest transport project in Europe which will create a new "ring" network that enables suburban travel without having to pass through the city of Paris (figure 2).

In the area of interest, the geological substratum is formed by Ludian (Priabonian) and Bartonian formations: supragypsous marls, gypsum masses and interstratified marls, infra-gypseous marls, Monceau green sand, St-Ouen limestone and Beauchamp sand, and Lutetian formations: marls and loose stones, sometimes clayey or sandy, and coarse limestone. These layers are covered at the surface by a quaternary cover of ancient and modern alluvion. These formations are synthesized in figure 3 up to a depth of $60 \mathrm{~m}$. These horizons contain gypsum beds presented in pink in figure 3. Data from the literature and that specific to this study (Thorin, 1986; Toulemont, 1987a; Charmoille, 2011; Charmoille et al., 2013) show strong lateral and vertical 
variations in the thickness of gypsum layers. This change is mainly due to the progressive loss of gypsum masses by sedimentary processes, dissolution and erosion. For instance, in the districts of Sevran, Tremblay and Villepinte, the levels above infragypseous marls have all been eroded and consequently only the $3^{\text {rd }}$ and $4^{\text {th }}$ masses of gypsum are still present in several areas. In other areas, all the gypsum masses have disappeared and the St-Ouen limestone are found near the surface (Toulemeont, 1970; Thierry et al., 2009). The thickness of gypsum horizons recorded into the Société du Grand Paris drilling database provides a better representation of this variability. The succession of permeable and poorly permeable levels makes it difficult to delimit the different aquifers. Three aquifers are generally identified in this area. The most superficial is the groundwater level of infra-gypseous marls, the second one is the aquifer of St-Ouen limestone and the deepest is the aquifer of the marls and loose stones.

Gypsum rocks can be present under different facies. These facies depend on the formation of gypsum minerals and their geological history. They can be combined with other sedimentary rocks, such as clay or limestone. Samples of fine-grained gypsum, composed of tiny crystals about $110 \mathrm{~nm}$, were used as reference. They were obtained from the underground gypsum quarry of Vaujours located into the $1^{\text {st }}$ gypsum mass layer. They present sacharoidal gypsum (figure 4a) with a low porosity (4 to $6 \%$ ) and they will be referred to as saccharoidal I. For the study, four types of natural gypsum (as shown respectively in figure $4 \mathrm{~b}, \mathrm{c}, \mathrm{d}, \mathrm{e}$ ) are taken from the exploratory drill cores of the Grand Paris Express project: 1) a sacharoidal gypsum, will be further called saccharoidal II, with a porosity of $9 \%$ which contains insoluble portions presented as yellow streak marks; 2) a gypsum with carbonate-clay matrix texture and a porosity of $10 \%$. It will be later referred to as matrix textured gypsum; 3) a milky white gypsum, called alabaster, with large-sized crystals and a porosity less than $1 \%$ and 4) an impure greyish-black alabaster contains dispersed clays and anhydrite. The mineralogical characteristics of each sample are summarized in table 1.

The first two facies are located into the $3^{\text {rd }}$ and $4^{\text {th }}$ gypsum mass layers and the two last ones in the Lutetian "marl and loose stones" formations. The extraction area is marked in figure 3. A north-south section of gypsum layers within the "marl and loose stones" Lutetian formation across the Seine-St-Denis department is also presented. It shows a synclinal basin where the cumulative thickness of alabaster gypsum can be significant (Sevran) while small deposits, found preferentially on the borders, are considered by Toulemont (1987a) as saccharoidal gypsum. Recent studies show that the nature of small deposits is more like calcite residue from dissolution and saccharoidal gypsum is mainly found in the infra-gypseous marls (Lamé, 2013; Kreziak and Dumont, 2018).

Several samples of high purity gypsum and with large crystals were used in batch experiments: 1) glassy arrowhead gypsum (figure 4f) and 2) so called "Pied d'alouette". Both are macled crystals collected into the marl layers separating the Ludian thick gypsum masses. 
4 Experimental procedures

4.1 Variation of the electrical conductivity with the concentration of $\mathrm{CaSO}_{4}, 2 \mathrm{H}_{2} \mathrm{O}$

The evolution of the solution concentration was monitored by recording the signal of a conductivity probe immersed into the solution. To verify the accuracy of quantifying the concentration from the electrical conductivity measurements, we performed a calibration by adding mass increments of ultra-pure gypsum powder $\left(\mathrm{CaSO}_{4}, 2 \mathrm{H}_{2} \mathrm{O}\right)$ in ultra-pure water and recording each time the conductivity $(\mathrm{mS} / \mathrm{cm})$ when the added mass is completely dissolved and the measured conductivity is stabilized. This process was repeated until there is no further increase in the conductivity even though undissolved particles are still visible in the solution. Measurements of the electrical conductivity in a supersaturated solution with gypsum are independent of the undissolved mass. The experimental measures exhibit a linear relationship in the first order as a function of the concentration. Therefore, the relative concentration $C_{r e l}=C / C_{r e f}$ is equal to the relative conductivity $\sigma_{r e l}=\sigma / \sigma_{r e f}$ with $\sigma_{r e f}$ the reference value of the conductivity at the saturation limit.

As with the concentration, the time dependence of the relative conductivity $\sigma_{r e l}$ is expressed by:

$$
\frac{d \sigma_{r e l}(t)}{d t}=\frac{A}{V} \tau_{0}\left(1-\sigma_{r e l}(t)\right)^{n}
$$

Where $\tau_{0}=\frac{k}{C_{r e f}}$ is the dissolution rate parameter in pure water $(\mathrm{cm} / \mathrm{s})$, henceforward called the effective recession rate for simplicity.

From the known values of pure gypsum molar mass and the volume of the solution, the molar concentration is expressed as a function of the electrical conductivity measurements (figure 5). The accuracy of the relationship can be enhanced by using a third degree polynomial fitting of the experimental measurements. This fitting gives the relation:

$$
C=3.82 .10^{-6} \sigma+1.82 \cdot 10^{-9} \sigma^{2}-2.32 .10^{-13} \sigma^{3}
$$

$C$ expressed in $\mathrm{mmol} / \mathrm{cm}^{3}$ and $\sigma$ in $\mathrm{nS} / \mathrm{cm}$. For practical purposes, measurements were performed with a WTW ${ }^{\mathrm{TM}} 3620$ conductivity meter and TetraCon ${ }^{\mathrm{TM}}$ graphite 4-electrode conductivity measuring cells for or small volume. Although this cell has a temperature compensation probe that automatically corrects conductivity measurements for variations due to temperature change, all measurements were performed by controlling the temperature of the solution, either by setting the container in a constant temperature water bath or by using a double-walled container with circulation of the water bath in the inner volume. This electrical conductivity meter allows automatic recording of measurements with a time interval equal to or greater than one second. Each measurement is time and date stamped and contains the measured values of conductivity and temperature.

This unit has an automatic range change to make measurements between $1 \mathrm{nS} / \mathrm{cm}$ and $2000 \mathrm{nS} / \mathrm{cm}$ with the used cells. In the case of a dissolution experiment, the conductivity of the solution varies between about $2 \mathrm{nS} / \mathrm{cm}$ (pure water) and 2200-2300 $\mathrm{nS} / \mathrm{cm}$ (saturated solution). When the conductivity of the solution is less than 2000 $\mathrm{nS} / \mathrm{cm}$ (far from the equilibrium), the measurement resolution is $1 \mathrm{nS} / \mathrm{cm}$ while close 
to equilibrium, when the conductivity is greater than $2000 \mathrm{nS} / \mathrm{cm}$, the resolution of the measurements is down to $10 \mathrm{nS} / \mathrm{cm}$. This implies a lower number of data points near equilibrium.

\subsection{Gypsum dissolution rate from rotating disk experiments}

A gypsum disk with a diameter of $50 \mathrm{~mm}$ is polished using different abrasive disks ranging from 400 to 2400 (grains $/ \mathrm{cm}^{2}$ ) with isopropyl alcohol lubricant. This process ensures a smooth surface of the disk without a significant roughness visible to the naked eye (Bruckenstein et al., 2002). The disk is fixed with paraffin in a Plexiglas holder so that only the surface of the disk is subjected to dissolution. The disk-holder assembly is mounted on a shaft attached to a rotary motor rotating at a constant velocity. The rotation of the immersed part of the holder contributes to homogenize the concentration of the solution. The disk surface is maintained centered about $2 \mathrm{~cm}$ above the bottom of a stainless-steel crystallizer containing $300 \mathrm{ml}$ of ultra pure water $(2 \mathrm{nS} / \mathrm{cm})$ or a gypsum solution at $64 \%$ saturation. The experimental apparatus is set into a water bath maintaining a constant temperature and covered with a silicone lid to limit the evaporation of the solution and to preserve the mass of the solvent. This lid has two holes allowing insertion of the rotating motor shaft and the conductivity sensor. Before starting the experiment, the disk-holder assembly is wrapped in a waterproof film and immersed in the water bath at a constant temperature for about an hour to ensure a small temperature difference at the beginning of the measurements. Measurements of the conductivity were recorded at constant time intervals until the saturation concentration is reached. Several experiments were carried out by setting different rotational speeds in order to quantify the reaction rate with a variation in the boundary layer characteristics. However, when the surface of the disk evolves with dissolution, the hydrodynamic conditions are no longer stable and only an overall dissolution rate can be evaluated. The evolution of mass loss is shown proportional to the rotational speed, in other words, related to the apparent surface of the sample per time unit. We performed the experiments at temperatures of 15 and $20^{\circ} \mathrm{C}$ and varied the rotation speed of $30 \mathrm{rpm}$ to $200 \mathrm{rpm}$.

Complementary solubility experiments were performed in order to assess the saturation state of the solution at the end of each rotating disk experiment. The experimental procedure consists of adding pieces of each tested gypsum facies to a $25 \mathrm{ml}$ closed flask containing pure water. The flasks were stored in a thermostatic water bath after being stirred for 24 hours to ensure the effective saturation of the solution. The conductivity of each solution was measured repeatedly before and after decantation at the temperatures 15 and $20^{\circ} \mathrm{C}$.

\subsection{Batch reactor experiments}

To determine the dissolution kinetics at the saturation state of the solution, the following protocol was adopted. A double wall thermostatic beaker in borosilicate glass is first filled with $80 \mathrm{ml}$ pure water $(\sim 2 \mathrm{nS} / \mathrm{cm})$. Once the temperature is stabilized at 
$20^{\circ} \mathrm{C}, 1 \mathrm{~g}$ of crushed gypsum particles with an equivalent diameter ranging between 500 and $800 \mathrm{~nm}$ obtained from the commonly used sieve analysis is added and maintained in suspension by vigorous stirring using a magnetic bar. The conductivity of the solution is recorded every second until reaching equilibrium using a conductivity probe. The beaker is covered with a parafilm $($ ) to avoid a drift of the measured concentration due to evaporation. Further batch tests were applied using different gypsum crystals and/or by adding silica or clay particles in order to see if these impurities can act as crystallization germs that could create a reaction and release gypsum at the interface (reprecipitation process).

\section{Results and discussion}

\subsection{Determination of kinetic rate parameters for the dissolution}

The data acquisition of the electrical conductivity of the solution starting from $\mathrm{C}=0$ to $\mathrm{C}=C_{\text {ref }}$ and the knowledge of the surface area of the disk A and the volume of the solution $\mathrm{V}$ allow us to determine $\tau_{0}$ and $\mathrm{n}$ of the rate law. This is done by a global fit of the theoretical conductivity curve to the experimental data using the least squares method. This interpretation method is based on the analytic solution of the conductivity obtained by solving the differential equation of the dissolution rate (eq 6). A time offset parameter $t_{f i x}$ is introduced into the boundary conditions to consider uncertainties about initial conditions while concentration is not well homogenized. For a given conductivity value, $\mathrm{t}_{\text {fix }}$ allows to use a low concentration measure instead if the first one as an initial fitting point. The expression of this solution is as follows:

$$
\begin{aligned}
t_{f i x} & =\frac{1-\left(1-\sigma_{r e l}\right)^{n-1}}{\tau_{0}(n-1)\left(1-\sigma_{r e l}\right)^{n-1}} \\
\sigma_{t h}(t) & =\sigma_{r e f}\left[1-\left(\frac{1}{1+\left(t+t_{f i x}\right)(n-1) \tau_{0}}\right)^{1 / n-1}\right]
\end{aligned}
$$

An example of a fit on the conductivity measurements as a function of time in a rotating disk experiment is shown in Figure 6. This method provides a very good fit, with deviations less than $\pm 5 \mu \mathrm{m} / \mathrm{s}$ corresponding to $20 \%$ of maximal relative error, mainly at early times. In the case of natural gypsum, the effective recession rate $(\mu \mathrm{m} / \mathrm{s})$ can be deduced from the dissolution coefficient $\left(\mathrm{mol} / \mathrm{m}^{2} / \mathrm{s}^{-1}\right)$ considering the actual porosity and density of the rock. It is supposed to characterize the surface velocity variations of a dissolution cavity or a gypsum lens in contact with a groundwater aquifer.

The evolution of the dissolution kinetic at a given rotation speed allows us to define, for each tested gypsum sample, an intrinsic value of the dissolution parameter in water at rest as well as the kinetic law order. Figure 7 shows the effective recession rates $\tau_{0}$ of the alabaster and sacharoidal disks as a function of $\omega$ at $\mathrm{T}=15$ and $20^{\circ} \mathrm{C}$. The difference in effective recession rates $\tau_{0}$ between these two facies can be explained by the identification of cleavage planes on the surface of alabaster disk 
after dissolution. These cleavages imply a significant increase in the relative surface area compared to the projected surface used in the calculations. The results of all the experiments are presented in Table 2. Values of dissolution rates are close, and they increase with temperature. Values of the kinetic order $\mathrm{n}$ show a dispersion around a mean value $n=1.12$ when the temperature or the rotation velocity varies. The significant uncertainties of the dissolution rate values are due to the difference in the characteristics of the surface sample between successive experiments. In fact, when performing experiments on an initially polished saccharoidal gypsum disk containing a patch of insoluble materials, a macroscopic roughness has developed during the experiment that disrupted the flow and therefore the data could not be interpreted. The solubility of gypsum samples in pure water at 15 and $20^{\circ} \mathrm{C}$ is just about the same $\left(C_{r e f}=15 \pm 0.3 \cdot 10^{-3} \mathrm{mmol} / \mathrm{cm}^{3}\right)$, very close to the reference value often found in literature $\left(C_{r e f} \approx 15 \cdot 10^{-3} \mathrm{mmol} / \mathrm{cm}^{3}\right)$ (Barton and Wilde, 1971; Christoffersen and Christoffersen, 1976; Lebedev and Lekhov, 1990; Jeschke et al., 2001; Colombani, 2012; Lebedev, 2015). This indicates that the experiments were carried out under similar conditions and they quantified pure dissolution rates $(\approx 1$ to $\left.8 \times 10^{-6} \mathrm{mmol} / \mathrm{cm}^{2} / \mathrm{s}^{-1}\right)$ consistent with previous studies for $\mathrm{C}<0.9 \mathrm{C}_{\text {ref }}\left(5 \pm 2 \times 10^{-6}\right.$ $\mathrm{mmol} / \mathrm{cm}^{2} / \mathrm{s}^{-1}$ ) (Colombani, 2008, 2012). However, the evolution of mass loss is appeared proportional to the rotational speed (figure 7), in other words, the variation of the rotational velocity induces an increase of the apparent surface exposed to dissolution rather than a variation of the boundary layer thickness which according to theory is proportional to $\omega^{-1 / 2}$ for a conventional rotating disk experience. This difference in evolution is due to a modification of the surface shape with the development of a surface roughness created by dissolution during experiments. The surface roughness disturbs the boundary layer thickness and the fluid flow. When performing experiments on sacharoidal disks containing more insoluble species, we did not obtain proper interpretations due to the appearance of an insoluble patch on the disk surface during dissolution that disrupted the flow, unlike the other sacharoidal facies presented where we have an overall translation of the plane surface during dissolution with a uniform roughness over the entire surface.

To study the influence of surface roughness, conventional rotating disk experiments were performed with different gypsum samples under controlled conditions similar to those described by (Jeschke et al., 2001). This experiment consists of immersing a polished disk in a gypsum solution initially saturated at about $64 \%$ and monitoring the conductivity over short period of time defined by a small increase in the conductivity of the solution $(10 \mathrm{nS} / \mathrm{cm})$. As shown in figure 8 , the evolution of the dissolution rate values obtained as function of the rotational speed at $\mathrm{T}=15^{\circ} \mathrm{C}$ is characterized by an exponent 0.5 according to Levich theory (Levich, 1962): $\tau=\alpha D^{2 / 3} \vartheta^{-1 / 6} \omega^{1 / 2}$. However, the results obtained under unconventional conditions with our rotating disk technique are characterized by an exponent greater than 0.5 and closer to the unit. This difference can be explained by the surface roughness developed by dissolution during our unconventional experiment conditions which disturb the stability of the hydrodynamic conditions at the fluid/gypsum interface. This implies that the presented results characterize the effective flow surface of a gypsum cavity rather than the flow of the boundary layer. Under such conditions, the surface in contact with the solvent will exhibit a natural roughness like the one acquired by the surface of 
disks during our unconventional rotating disk experiments. In addition, conventional rotating disk experiments are sensitive to the initial temperature difference between the disk and the solution, which led us to prefer the unconventional procedure. The development of surface roughness during our rotating disk experiments was evaluated by determining a local exponent value associated to a conductivity increment $(10 \mu \mathrm{S} / \mathrm{cm})$ along the global curve between 15 and 80\% saturation. Figure 9 shows that the exponent varies considerably during the experiment. This reflects the increase of surface roughness over time and its influence on the dissolution kinetics. To determine the dissolution rates for each facies as function of surface roughness, we performed the same previous experiments but with gypsum disks that already have a superficial roughness acquired by dissolution. The main motive is to compare the rate found under a perfect surface condition to the practical rate that considers the rough texture of a gypsum rock in contact with underground flow. The recession rate obtained using disks with rough surface as function of $\omega$ are presented in figure 10 for various gypsum samples at $\mathrm{T}=15^{\circ} \mathrm{C}$. Tables 3 and 4 compare the values obtained with and without polishing the disk by using two different adjustment methods: a) a linear adjustment in the form $\tau=\tau_{0}+\alpha \omega$ is used to determine the recession rate at zero rotation speed $\tau_{0}$ and the slope of the curve $\alpha$; b) a fitting based on a power function $\tau=\tau_{0}^{\prime} \times \omega^{\beta}$ determines a constant associated with the intrinsic recession rate $\tau_{0}^{\prime}$ and the exponent $\beta$ of the rotational speed with $\omega$ expressed in $\mathrm{rad} / \mathrm{s}$. Results are close for gypsum samples but they present differences that can be linked to the roughness acquired by the facies and the presence of insoluble materials.

For the matrix textured gypsum, the dissolution is preferentially located at the surface of the gypsum grains intersected by the initial surface. This leads to the formation of large pores and the persistence of the insoluble residue present in the initial surface. This insoluble residue develops a large amplitude roughness unlike the other samples tested (sacharoidal or alabaster gypsum) that present a small amplitude roughness which develops over the entire surface and which remains constant during the surface recession time evolution, without the presence of patches or insoluble particles. When the impurities are very fine-grained, large amplitude roughness are mechanically eroded during the experiment under the effect of the rotational movement of the fluid flow. However, the eroded relief remains constant and because it is composed of insoluble minerals, the surface is protected from the dissolution by a coating effect. In the case of other facies, when the patches of insoluble are more important in terms of volume, they present a more significant relief that does not follow the recession of the surface exposed to dissolution. The localized undissolved materials create flow perturbations, resulting in large variations in the recession rate for a given rotation speed (figure 10b), but these differences are smaller for the values of the reference recession rate i.e. at zero rotation speed. This is consistent with the fact that in the case of no transport, the boundary layer is theoretically no longer disturbed by the flow and it is only influenced by the shape or the morphology of the surface.

Therefore, for homogeneous textured gypsum (sacharoidal gypsum of Vaujours) and gypsum with high insoluble materials (matrix textured gypsum, impure alabaster), the recession rate values from unconventional experiments with polished disks are representative of the effective recession rate of natural surfaces and for gypsum with important insoluble patches, the values obtained with polished disks underestimate 
those of natural surfaces.

To confirm the effect of insoluble materials on the dissolution kinetics, rotating disk experiments were performed on matrix textured gypsum disks having initially a deep roughness. The recession rate is found very low compared to the recession rates of a polished disks or a disk having initially a superficial roughness (see table 5). Therefore, the insoluble materials serve as coatings that protect the gypsum grains and drastically slows down the dissolution kinetics.

5.2 Characterization of the dissolution kinetics at the saturation state of the solution

\subsubsection{Review of the rotating disk experiments at equilibrium}

The rotating disk method shows linear dissolution kinetic, but it has low accuracy of the measurements close to equilibrium i.e. above $0.9 C_{r e f}$, when dissolution rates become extremely low. Observations of the gypsum disks and the surface of the solution at the end of these experiments (figure 11) may indicate recrystallization and/or supersaturation phenomenon. The solubility studies carried out on the same samples mentioned above show systematically that the conductivity of the reference flask is higher than the conductivity at the end of the rotating disk experiment (from 0.3 to $1 \%)$. This difference may be due to the super saturation of the solution, but it cannot be due to the presence of insoluble particles because the values of the conductivity of the solution before and after decantation were found to be identical.

This has led us to evaluate the dissolution kinetics at the saturation state of the solution by performing batch tests. The goal is to verify if there is a significant change in kinetics close to saturation, where there is not an end of dissolution, but an equilibrium between dissociation and crystallization that occurs.

\subsubsection{Batch experiment results}

The dissolution rates were determined at different time as follows: first, we performed a local parabolic adjustment with the measurements of electrical conductivity to determine the leading coefficients of a second degree polynomial function in a given time-centered interval. Then, each value of the tangent to the parabolic curve was assigned to that of the derivative of the conductivity and subsequently the dissolution rate. The amplitude time interval used to perform the parabolic adjustment increases with time to reduce the level of spurious oscillations and to improve the resolution. The linear regressions on the log-log curves of the dissolution rate as a function of (1$\sigma_{e q}$ ) for four tested samples (figure 12) allow us to determine the values of dissolution coefficients and kinetic order of a kinetic law following eq 7.

Results clearly show double dissolution domains. The kinetic order values far from equilibrium are in close agreement with the ones found using the rotating disk method. Concentrations close to equilibrium show also a linear variation but with greater slope of around 3. The intersection of these two lines defines the value of a transition relative concentration which is relatively close to $0.94 \mathrm{C}_{\text {ref }}$. The dissolution rates are strongly influenced by the morphology of particles (steps, ledges and kinks 
on the surface). To reduce the error factor, we used a reference value of the roughness factor $(\varepsilon=1100 / 60)$ reported in previous research (Colombani and Bert, 2007) to correct our measures. Results in table 6 show that the dissolution rates $\tau_{01}$ far from equilibrium are about five times higher than the dissolution rates found with the rotating disk method which could be due to the uncertainty on particle size and shape (a sphere or a cube-like particle). The dissolution rates close to equilibrium $\tau_{02}$ are found about 30 times higher than the values of the first kinetics.

This non-ideal behavior at high concentrations is probably due to the increase of impurities from insoluble materials present in the gypsum and the mineral crystallinity. Figure 12 shows that for the macro-crystalline gypsum called arrowhead gypsum, the exponent of the second kinetics is lower than for the other samples tested because it contains small amount of impurities which implies low germination rates. Afterward, other batch tests were performed using gypsum crystals of the glassy arrowhead gypsum and adding silica or clay particles to see if these impurities would serve as crystallization nuclei that could induce a reaction and decrease the apparent dissociation of gypsum at the interface. The results do not show significant changes in the dissolution kinetics if impurities are added to the solution.

Points located towards the end of curves in figure 12 are not aligned with the fitting line. This is linked to the poor resolution of the conductivity measurement above a relative saturation of $99 \%$. There is also an uncertainty around the value of the final concentration $\mathrm{C}_{r e f}$. This value varies according to the facies and the duration of the test and it is found close to the values found using the rotating disk method within a few tens of $\mu \mathrm{S} / \mathrm{cm}$. It is then possible to correct the curves by forcing the saturation value. However, small variations of 10 to $30 \mu \mathrm{S} / \mathrm{cm}$ on the value of $\mathrm{C}_{r e f}$ (figure 13) have a large influence on the exponent $\mathrm{n}_{2}$, a lower one on the transition relative concentration. The influence on the $\tau_{02}$ value of the second kinetics is very large. Thus, there may be a potential bias in the value of the concentration at the end of the experiment due to an error in the experimental data or conditions, which implies a high uncertainty on the parameters of the double kinetics.

Until now, it has not been possible to establish a direct influence of insoluble material, naturally present or in addition into the solution, to explain this high order kinetics close to saturation. However, many factors affecting the precision of the experimental results are identified: the measurement conditions (measurement uncertainty related to the automatic range change), the definition of the equilibrium concentration $\mathrm{C}_{r e f}$ (theoretical or experimental) unaffected by over-saturation phenomena and the uncertainties of a log-log interpretation in batch tests. This gathered information allows us to put into perspective the value of this reaction order and to assign it a high uncertainty.

\section{Conclusions}

In this study, we have examined the dissolution kinetics of various gypsum facies with different texture, porosity and insoluble content under controlled conditions by measuring the dissolution rates using rotating disks and batch reactor experiments. Presented results using rotating disks, initially polished, are in close agreement with 
previous studies for $\mathrm{C}<0.9 \mathrm{C}_{\text {ref }}$ (Barton and Wilde, 1971; James and Lupton, 1978; Lebedev and Lekhov, 1990; Jeschke et al., 2001; Colombani, 2012; Lebedev, 2015). Further experiments were carried out with gypsum disks initially having a roughness acquired by a dissolution. The objective is to evaluate the possibility to quantify a dissolution rate closer to a "practical" rate representative of in situ conditions.

By comparing the results obtained with dissolved or polished disks, it is possible to define a correction factor according to the specific roughness and the sample texture. Pure sacharoidal gypsum made of small-sized crystals acquire a small amplitude roughness that does not modify the recession rate. At the opposite, pure alabaster gypsum made of large-sized crystals which also acquire a small amplitude roughness present a large increase of the recession rate due to a preferential dissolution along large well-developed cleavage planes that increases the effective surface in contact with the solution. The presence of insoluble materials could have an opposite effect. If their content is low and if they are localized, relative reliefs are formed and this could enhance the dissolution by locally perturbing flow conditions. If the insoluble content is large, these reliefs present a large extension and the recession rate is lightly lowered due to the reduction of the surface exposed to dissolution. But when insoluble materials are present at the boundaries of gypsum grains, a large amplitude roughness was observed and even if it is eroded, insoluble material remain along grains surfaces and the recession rate is strongly reduced by a coating effect.

The rotating disk method is efficient and used widely for measurements under uniform and constant conditions but has a low resolution as the fluid saturation approaches where the dissolution rate becomes extremely low. Batch gypsum dissolution tests were therefore performed to verify if there is a change in kinetics near the saturation of the solution and if it corresponds to a balance between dissociation and crystallization processes that probably coexist at the solid/liquid interface. For the studied samples, results confirmed a double kinetics and a value of the transition relative concentration relatively close to $94 \%$. This non-ideal behavior at high concentrations can be explained by the increase in solid impurities from insoluble materials present in the gypsum, which could constitute germs inducing the crystallization of the mineral. Observations of batch tests performed on pure gypsum crystals with the addition of impurities (silica or clay) does not show an effect on dissolution kinetics. However, the order of the double kinetics and the relative transition concentration values vary strongly with small variations in $\mathrm{C}_{r e f}$ which may have a bias related to the concentration value at the end of the batch test.

\section{Acknowledgements}

This research work was supported by Ineris in the framework of a partnership with the Société du Grand Paris which financially supports a part of this study and facilitate access to data and core samples collected during the geological and hydrogeological characterization of the future Grand Paris Express subway line. 


\section{Compliance with Ethical Standards}

Conflict of interest the authors declare that they have no conficts of interest.

\section{References}

Alkattan M, Oelkers EH, Dandurand JL, Schott J (1997) Experimental studies of halite dissolution kinetics, the effect of saturation state and the presence of trace metals. Chemical Geology 137(3-4):201-219

Barton AFM, Wilde NM (1971) Dissolution rates of polycrystalline samples of gypsum and orthorhombic forms of calcium sulphate by a rotating disc method. Transactions of the faraday society 67:3590-3597

Beyssac E, Lavigne J (2005) Dissolution study of active pharmaceutical ingredients using the flow through apparatus usp 4. Dissolution Technologies p 23

Bruckenstein S, Sharkey JW, Yip JY (2002) Effect of polishing with different size abrasives on the current response at a rotating disk electrode. Analytical Chemistry 57(1):368-371

Burgos-Cara A, Putnis C, Rodriguez-Navarro C, Ruiz-Agudo E (2016) Hydration effects on gypsum dissolution revealedby in situ nanoscale atomic force microscopy observations. Geochimica et Cosmochimica Acta (179):110-122

Chardon M, Nicod J (1996) Gypsum karst of france. International Journal of Speleology 25(3-4):203-208

Charmoille A (2011) Etude des processus de dissolution affectant le sous-sol du bois de la tussion (seine-saint-denis), evaluation de l'aléa et proposition de solutions d'aménagements adaptées. Tech. rep., Ineris, Verneuil-en-Halatte, France

Charmoille A, Lecomte A, Daupley X (2013) Evaluation de l'aléa mouvements de terrain lié à la dissolution du gypse sur les communes de sevran, villepinte et tremblay, seine-saint-denis, Île-de-france. Tech. rep., Ineris, Verneuil-en-Halatte, France

Charmoille A, Lecomte A, Kreziak C (2018) Dissolution naturelle du gypse dans le sous-sol. Tech. rep., Ineris \& Cerema

Christoffersen J, Christoffersen M (1976) The kinetics of dissolution of calcium sulphate dihydrate in water. Journal of Crystal Growth 35(1):79-88

Colombani J (2008) Measurement of the pure dissolution rate constant of a mineral in water. Geochimica et Cosmochimica Acta 72(23):5634-5640

Colombani J (2012) Dissolution measurement free from mass transport. Pure and Applied Chemistry 85(1):61-70

Colombani J, Bert J (2007) Holographic interferometry study of the dissolution and diffusion of gypsum in water. Geochimica et Cosmochimica Acta 71(8):19131920

Dai Z, Kan AT, Shi W, Zhang N, Zhang F, Yan F, Bhandari N, Zhang Z, Liu Y, Ruan G, Tomson MB (2016) Solubility measurements and predictions of gypsum, anhydrite,and calcite over wide ranges of temperature, pressure,and ionic strength with mixed electrolytes. Rock Mech Rock Eng 50:327-339 
Daupley X, Laouafa F, Billiotte J, Quintard M (2016) La dissolution du gypse : quantifier les phénomènes. Mines \& Carrières société de l'industrie minérale pp 35-43

Diffre P (1972) Hydrogéologie de paris et de sa banlieue. La Houille Blanche (8):665 $-671$

Dokoumetzidis A, Macheras P (2006) A century of dissolution research: From noyes and whitney to the biopharmaceutics classification system. International Journal of Pharmaceutics 321:1-11

Dove PM, Platt FM (1996) Compatible real-time rates of mineral dissolution by Atomic Force Microscopy (AFM). Chemical Geology 127(4):331-338

Dreybrodt W (1996) Principles of Early Development of Karst Conduits Under Natural and Man-Made Conditions Revealed by Mathematical Analysis of Numerical Models. Water Resources Research 32(9):2923-2935

Durie R, Jessen F (1964) Mechanism of the dissolution of salt in the formation of underground salt cavities. Society of Petroleum Engineers 4(2):183-190

Egal E, Kreziak c, Saitta A, Marlinge J, Priol G (2017) Méthodologie de détection des zones déstructurées et des cavités dans les terrains gypseux parisiens le long de la ligne 16 du grand paris express. Congrès International de l'AFTES

Gregory DP, Riddiford AC (1956) 731. transport to the surface of a rotating disc. Journal of the Chemical Society (Resumed) pp 3756-3764

Guo $\mathrm{J}$ (2015) Modélisation numèrique de la dissolution des cavitès karstiques. $\mathrm{PhD}$ thesis, université de Toulouse

Guo J, Laouafa F, Quintard M (2016) A theoretical and numerical framework for modeling gypsum cavity dissolution: modeling gypsum cavity dissolution. International Journal for Numerical and Analytical Methods in Geomechanics 40(12):1662-1689

Gysel M (2002) Anhydrite dissolution phenomena: Three case histories ofanhydrite karst caused by water tunnel operation. Rock Mech Rock Eng 35:1-21

James A, Lupton A (1978) Gypsum and anhydrite in foundations of hydraulic structures. Geotechnique 28(3):249-272

Jaworska J (2012) Crystallization, alternation and recrystallization of sulphates. In: Advances in crystallization processes, Adam Mickiewicz University. Poland., chap 18, pp 465-490

Jeschke AA, Dreybrodt W (2002) Dissolution rates of minerals and their relation to surface morphology. Geochimica et Cosmochimica Acta 66(17):3055-3062

Jeschke AA, Vosbeck K, Dreybrodt W (2001) Surface controlled dissolution rates of gypsum in aqueous solutions exhibit nonlinear dissolution kinetics. Geochimica et Cosmochimica Acta 65(1):27-34

Klimchouk A (1996) Dissolution and conversions of gypsum and anhydrite. International Journal of Speleology 25(3):21-36

Kreziak C, Dumont E (2018) Caractérisation des mécanismes de dissolution du gypse projet de recherche et de développement. Tech. rep., Cerema, Trappes, France

Labourguigne P, Mégnien C, Rampon G (1972) Etude de la répartition géographique du gypse antéludien et des risques engendrés par sa dissolution dans le nord-est de la région parisienne. BRGM, Orleans, France

Lamé A (2013) Modélisation hydrogéologique des aquifères de paris et impacts des aménagements du sous-sol sur les écoulements souterrains. PhD thesis, MINES 
ParisTech, France

Lasaga A (1998) Kinetic Theory in the Earth Sciences. Princeton University Press, Princeton

Lebedev AL (2015) Kinetics of gypsum dissolution in water. Geochemistry International 53(9):811-824

Lebedev AL, Lekhov A (1990) Dissolution kinetics of natural-gypsum in water at 5-25 $5^{\circ}$. Lomonosov Moscow State University 27:85-94

Levich VG (1962) Physiochemical Hydrodynamics, prentice-hall edn. Englewood Cliffs, N.J., United Kingdom

Liu ST, Nancollas G (1971) The kinetics of dissolution of calcium sulfate dihydrate. Journal of Inorganic and Nuclear Chemistry 33(8):2311-2316

Luo H, Laouafa F, Guo J, Quintard M (2014) Numerical modeling of three-phase dissolution of underground cavities using a diffuse interface model. International Journal for Numerical and Analytical Methods in Geomechanics 38(15):1600 1616

Marteau P (1993) Mémento roches et minéraux industriels Gypse et anhydrite. Tech. rep., BRGM, Orleans, France

Palmer AN (1991) Origin and morphology of limestone caves. Geological Society of America Bulletin 103(1):1-21

Prunier-Leparmentier AM, David O, Schönberg M (2007) Dissolution du gypse à Paris: efficacité et carences de la réglementation. In: XIV ${ }^{e s}$ journées techniques du comité français d'hydrogéologie. Lyon, Inspection générale des carrières (IGC), pp 205-213

Raines MA, Dewers TA (1997) Mixed transport reaction control of gypsum dissolution kinetics in aqueous solutions and initiation of gypsum karst. Chemichal Geology 140(1-2):29-48

Rickard D, Sjoeberg EL (1983) Mixed kinetic control of calcite dissolution rates. American Journal of Science 283(8):815-830

Rolnick LS (1954) The stability of gypsum and anhydrite in the geologic environment. PhD thesis, Massachusetts Institute of Technology. USA

Sadeghiamirshahidi M, Vitton SJ (2018) Analysis of drying and saturating natural gypsum samples for mechanical testing. Journal of Rock Mechanics and Geotechnical Engineering

SGP (2016) Volet E.2: Etude d'impact état initial. Tech. rep., Société du Grand Paris, Saint-Denis, France

Shiraki R, Brantley SL (1995) Kinetics of near-equilibrium calcite precipitation at $100^{\circ} \mathrm{C}$ : An evaluation of elementary reaction-based and affinity-based rate laws. Geochimica et Cosmochimica Acta 59(8):1457-1471

Stawski TM, van Driessche AE, Ossorio M, Diego Rodriguez-Blanco J, Besselink R, Benning LG (2016) Formation of calcium sulfate through the aggregation of sub-3 nanometre primary species. Nature Communications 7(11177):

Sun J, Wang L, Yu G (2015) Effects of $\mathrm{Na}, \mathrm{Ca}, \mathrm{Mg}$, and Al Chloride Salts on Dissolution and Phase Stability of Calcium Sulfate Dihydrate in Aqueous Solutions at 278.15 K to 308.15 K. J Chem Eng Data (60):2259-2566

Thierry P, Prunier-Leparmentier AM, Lembezat c, Vanoudheusden E, Vernoux JF (2009) 3d geological modelling at urban scale and mapping of ground movement 
susceptibility from gypsum dissolution: The paris example (france). Engineering Geology 105:51-64

Thorin R (1986) Caractéristiques des masses et marnes du gypse et de leurs faciès d'altération dans la région parisienne méthodologie des études géotechniques. Bulletin of the International Association of Engineering Geology 33:73-89

Toulemeont M (1970) Observations géologiques sur les accidents de dissolution du gypse dans la région parisienn. In: Congrés international de géologie de l'ingénieur, Inspection générale des carrières (IGC), pp 89-98

Toulemont M (1987a) Les Gypses lutétiens du bassin de Paris sédimentation, karstification et conséquences géotechniques, géotechnique-mécanique des sols-sciences de la terre GT-24 edn. Rapports des laboratoires, Laboratoire central des ponts et chaussées, France

Toulemont M (1987b) Les risques d'instabilité liés au karst gypseux Lutétien de la région parisienne. Prevision en cartographie pp 109-116

Vieillefon J (1979) Contribution à l'amélioration de l'étude analytique des sols gypseux. Cahiers ORSTOM: Série pédologie 17(3):195-223

Wang F, Davis TE, Tarabara VV (2010) Crystallization of Calcium Sulfate Dihydrate in the Presence of Colloidal Silica. Industrial \& Engineering Chemistry Research 49(22):11344-11350

Zareeipolgardan B, Piednoir A, Colombani J (2017) Gypsum Dissolution Rate from Atomic Step Kinetics. Journal of Physical Chemistry C, American Chemical Society $17(121): 9325$ 
Table 1 Mineralogical characteristics of gypsum samples (see chapter 3)

\begin{tabular}{|l|c|c|c|l|}
\hline Gypsum sample & $\begin{array}{c}\text { porosity } \\
(\%)\end{array}$ & $\begin{array}{c}\text { grain size } \\
(\mathrm{nm})\end{array}$ & $\begin{array}{c}\text { insoluble rate } \\
(\%)\end{array}$ & \multicolumn{1}{|c|}{ insoluble minerals } \\
\hline sacharoidal I & 6 & $80-140$ & 1.4 & calcite, quartz, dolomite, clay... \\
\hline sacharoidal II & 9 & $120-200$ & 11 & calcite, quartz, ferroan dolomite, ankerite... \\
\hline matrix textured & 10 & $140-940$ & 4 & calcite, quartz, dolomite, ferroan dolomite, anhydrite... \\
\hline alabaster & $<1$ & $210-350$ & 2.6 & \\
\hline impure alabaster & 1 & $90-120$ & 15 & calcite, quartz, dolomite, ferroan dolomite... \\
\hline
\end{tabular}

Table 2 Values of dissolution parameters by using a global fit of the dissolution data at $T=15$ and $20^{\circ} \mathrm{C}$

\begin{tabular}{|c|c|c|c|c|c|c|c|}
\hline Gypsum sample & $\begin{array}{c}\mathrm{T} \\
\left({ }^{\circ} \mathrm{C}\right)\end{array}$ & $\begin{array}{c}\tau_{0} \\
(\mathrm{~nm} / \mathrm{s})\end{array}$ & $\begin{array}{c}\tau_{0} \times 10^{-3} \\
\left(\mathrm{~g} / \mathrm{m}^{2} s\right)\end{array}$ & $\begin{array}{c}\text { Rel. Error } \\
\pm(\%)\end{array}$ & $\begin{array}{c}\mathrm{C}_{\text {ref }} \\
(\mathrm{mmol} / \mathrm{L})\end{array}$ & $\mathrm{n}$ & $\begin{array}{c}\text { Rel. Error } \\
\pm(\%)\end{array}$ \\
\hline \multirow{2}{*}{ alabaster } & 15 & 2.09 & 5.47 & 7 & 15.2 & 1.09 & 4 \\
\cline { 2 - 8 } & 20 & 5.61 & 14.5 & 6 & 15 & 1.12 & 6 \\
\hline \multirow{2}{*}{ impure alabaster } & 15 & 3.28 & 8.75 & 9 & 15.5 & 1.04 & 4 \\
\cline { 2 - 8 } & 20 & 3.63 & 9.31 & 3 & 14.9 & 1.16 & 7 \\
\hline \multirow{2}{*}{ saccharoidal I } & 15 & 1.02 & 2.72 & 11 & 15.5 & 1.12 & 8 \\
\cline { 2 - 8 } & 20 & 1.12 & 2.87 & 16 & 14.9 & 1.16 & 3 \\
\hline \multirow{2}{*}{ saccharoidal II } & 15 & 3.58 & 9.62 & 9 & 15.6 & 1.13 & 8 \\
\cline { 2 - 8 } & 20 & 4.56 & 11.9 & 6 & 15.2 & 1.22 & 7 \\
\hline \multirow{2}{*}{ matrix textured } & 15 & 1.8 & 4.93 & 3 & 15.9 & 1.19 & 7 \\
\cline { 2 - 8 } & 20 & 2.2 & 5.91 & 11 & 15.6 & 1.22 & 5 \\
\hline
\end{tabular}

Table 3 Values of dissolution parameters by using a linear regression at $T=15^{\circ} \mathrm{C}$

\begin{tabular}{|c|c|c|c|c|c|}
\hline \multicolumn{2}{|c|}{ Gypsum sample } & $\begin{array}{c}\tau_{0} \\
(\mathrm{~nm} / \mathrm{s})\end{array}$ & $\begin{array}{c}\tau_{0} \times 10^{-3} \\
\left(\mathrm{~g} / \mathrm{m}^{2} \mathrm{~s}\right)\end{array}$ & $\begin{array}{c}\text { Rel. Error } \\
\pm(\%)\end{array}$ & $\begin{array}{c}\text { Coefficient } \\
\alpha\end{array}$ \\
\hline \multirow{2}{*}{ alabaster } & polished & 2.09 & 5.47 & 7 & 0.86 \\
\cline { 2 - 6 } & unpolished & 4.37 & 10.9 & 7 & 0.93 \\
\hline \multirow{2}{*}{ impure alabaster } & polished & 3.28 & 8.75 & 9 & 0.13 \\
\cline { 2 - 6 } & unpolished & 3.3 & 8.24 & 2 & 0.29 \\
\hline \multirow{2}{*}{ saccharoidal I } & polished & 1.02 & 2.72 & 11 & 0.55 \\
\cline { 2 - 6 } & unpolished & 1.88 & 4.69 & 2 & 0.88 \\
\hline \multirow{2}{*}{ saccharoidal II } & polished & 3.58 & 9.62 & 9 & 0.46 \\
\cline { 2 - 6 } & unpolished & 4.3 & 10.8 & 13 & 0.47 \\
\hline \multirow{2}{*}{ matrix textured } & polished & 1.8 & 4.93 & 3 & 0.32 \\
\cline { 2 - 6 } & unpolished & 1.85 & 4.75 & 6 & 0.44 \\
\hline
\end{tabular}


Table 4 Values of dissolution parameters by using power-law fitting at $T=15^{\circ} \mathrm{C}$ (see section 5.1)

\begin{tabular}{|c|c|c|c|c|}
\hline \multicolumn{2}{|c|}{ Gypsum sample } & $\begin{array}{c}\text { Exponent of } \\
\omega\end{array}$ & $\begin{array}{c}\text { Rel. Error } \\
\pm(\%)\end{array}$ & $\begin{array}{c}\text { Intrinsic parameter } \\
\tau_{0}^{\prime}\left(\times 10^{-2}\right)\end{array}$ \\
\hline \multirow{2}{*}{ alabaster } & polished & 0.8 & 2 & 1.7 \\
\cline { 2 - 5 } & unpolished & 0.69 & 4 & 2.9 \\
\hline \multirow{2}{*}{ impure alabaster } & polished & 0.32 & 2 & 2.3 \\
\cline { 2 - 5 } & unpolished & 0.5 & 2 & 2.13 \\
\hline \multirow{2}{*}{ saccharoidal I } & polished & 0.85 & 5 & 0.93 \\
\cline { 2 - 5 } & unpolished & 0.82 & 2 & 1.66 \\
\hline \multirow{2}{*}{ saccharoidal II } & polished & 0.56 & 3 & 2.32 \\
\cline { 2 - 5 } & unpolished & 0.66 & 9 & 2.66 \\
\hline \multirow{2}{*}{ matrix textured } & polished & 0.63 & 0.2 & 1.23 \\
\cline { 2 - 5 } & unpolished & 0.7 & 1 & 1.27 \\
\hline
\end{tabular}

Table 5 Effect of insoluble materials on the dissolution kinetics for matrix textured gypsum (see section 5.1)

\begin{tabular}{|c|c|c|}
\hline $\begin{array}{c}\text { Matrix textured gypsum } \\
\text { (initial state) }\end{array}$ & $\begin{array}{c}\text { recession rate } \\
(\mathrm{nm} / \mathrm{s})\end{array}$ & insoluble materials effect \\
\hline polished & 1.82 & \\
\hline superficial roughness & 1.85 & roughness effect \\
\hline deep roughness & 0.94 & coating effect \\
\hline
\end{tabular}

Table 6 Summary of the batch experiment results (see section 5.2.2)

\begin{tabular}{|c|c|c|c|c|}
\hline Crushed samples & $\begin{array}{c}\tau_{01} \\
\left(\times 10^{-5} \frac{\mathrm{mmol}}{\mathrm{cm}^{2} s}\right)\end{array}$ & $\mathrm{n}_{1}$ & $\begin{array}{c}\tau_{02} \\
\left(\times 10^{-4} \frac{\mathrm{mmol}}{\mathrm{cm}^{2} \mathrm{~s}}\right)\end{array}$ & $\mathrm{n}_{2}$ \\
\hline alabaster & 1.4 & 1.19 & 4.78 & 2.53 \\
\hline saccharoidal I & 1.08 & 1.24 & 2.46 & 2.35 \\
\hline saccharoidal II & 4.73 & 1.45 & 12,8 & 3.04 \\
\hline matrix textured & 0.87 & 1 & 2.58 & 2.17 \\
\hline
\end{tabular}




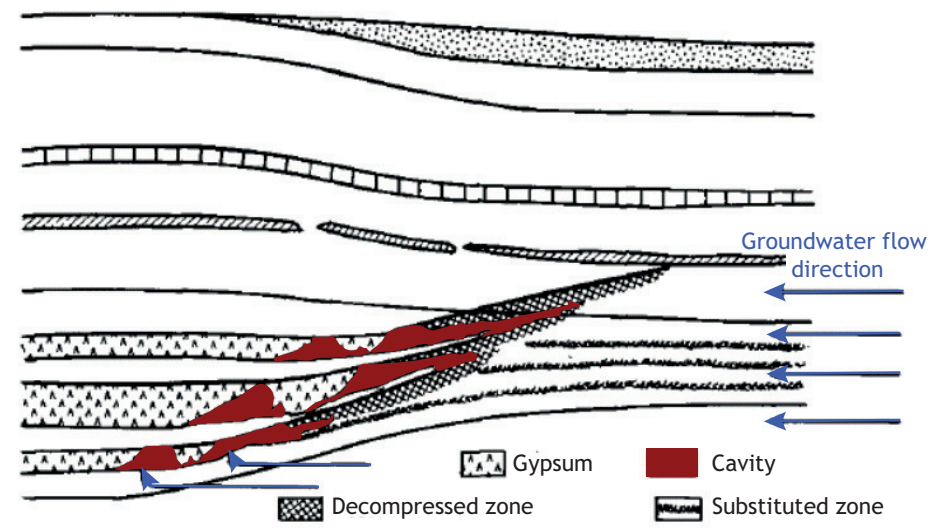

Fig. 1 Geological model of gypsum dissolution in the "marl and loose stones" Lutetian formations after Toulemont (1987a) modified by Charmoille et al. (2013)

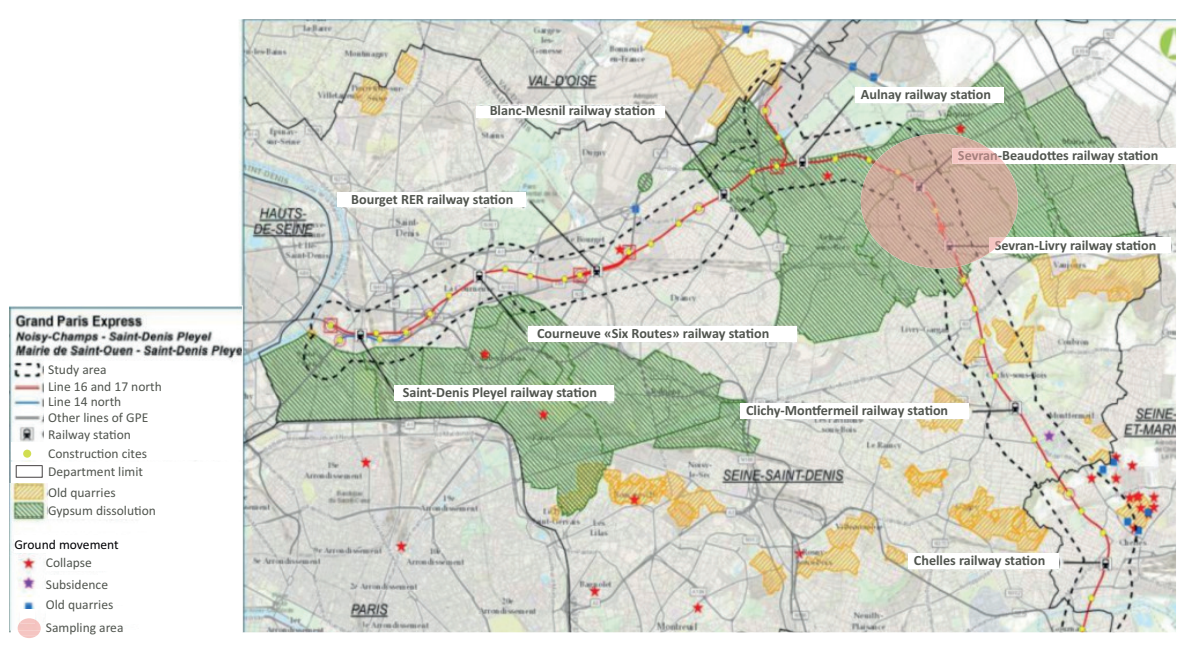

Fig. 2 Localization of the study area along the future Grand Paris Express metro line (SGP, 2016) (in chapter 3) 
Ages Geological formation million years

W

Modern alluvion
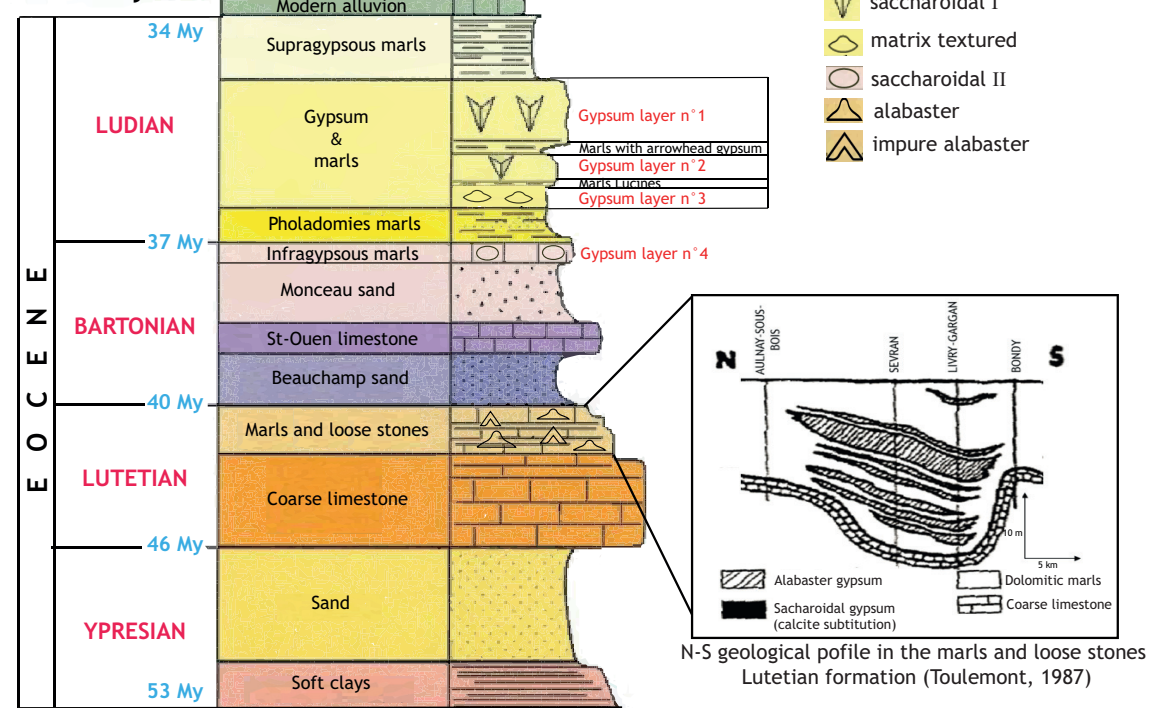

Fig. 3 Stratigraphic column of geological layers encountered in the Seine-Saint-Denis department (Sevran-Livry) (Egal et al., 2017) (in chapter 3)

\section{Gypsum samples}

M saccharoidal I

matrix textured

saccharoidal II

$\triangle$ alabaster

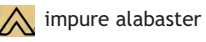




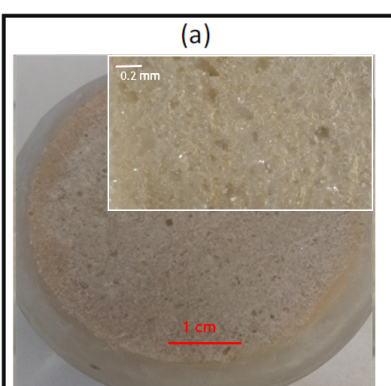

(d)

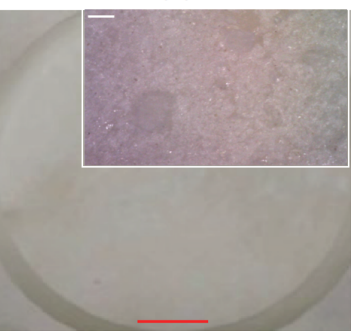
alabaster f) glassy arrowhead. The small frames show observations by Dino-Lite digital microscope camera (see chapter 3)

(c)

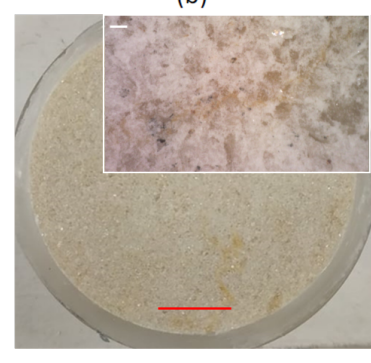

(e)

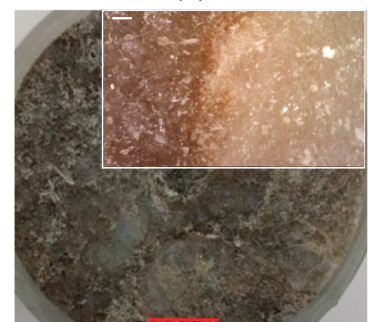

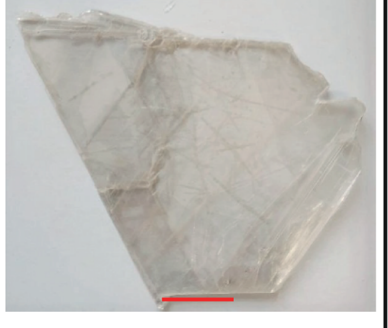

(f)

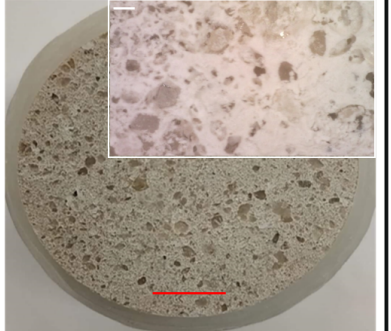

\section{政}




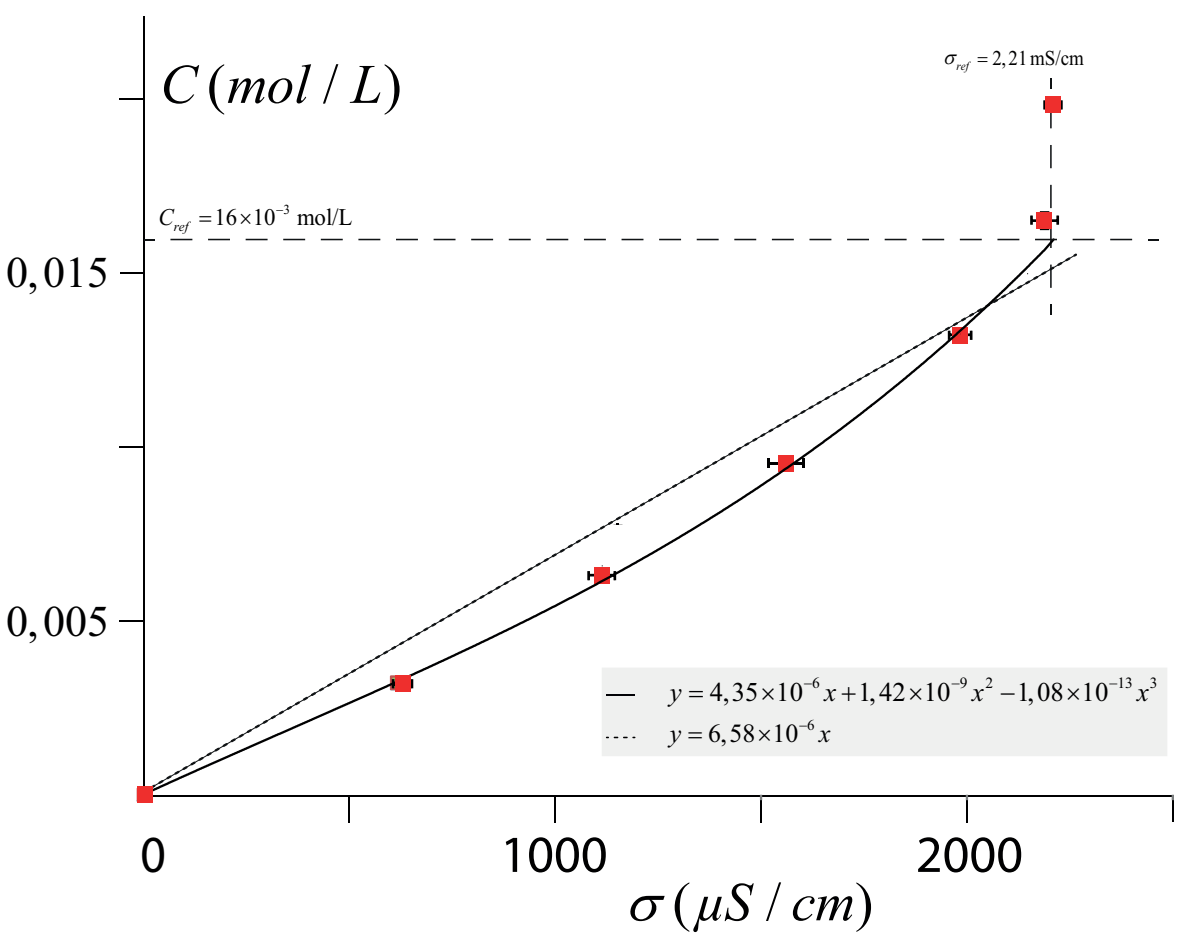

Fig. 5 Evolution of gypsum concentration as a function of the electrical conductivity (in section 4.1)

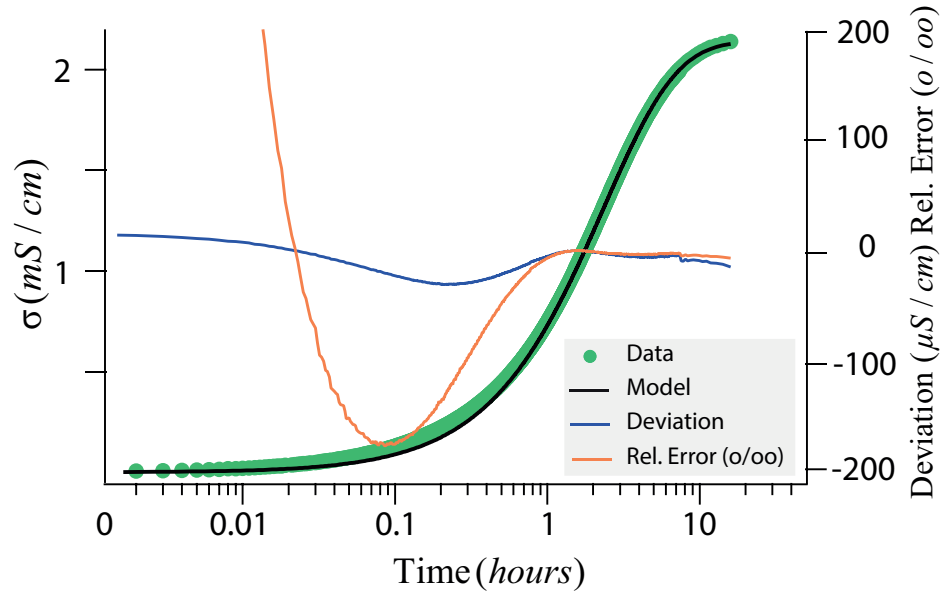

Fig. 6 Dissolution parameters by fitting the experimental data for sacharoidal gypsum II ( $\omega=100 \mathrm{rpm}$; $\mathrm{T}=15^{\circ} \mathrm{C}$ ): $\tau_{0}=8.36 \pm 0.37 \mathrm{~nm} / \mathrm{s}$ and $\mathrm{n}=1.1$ (in section 5.1 ) 
(a)

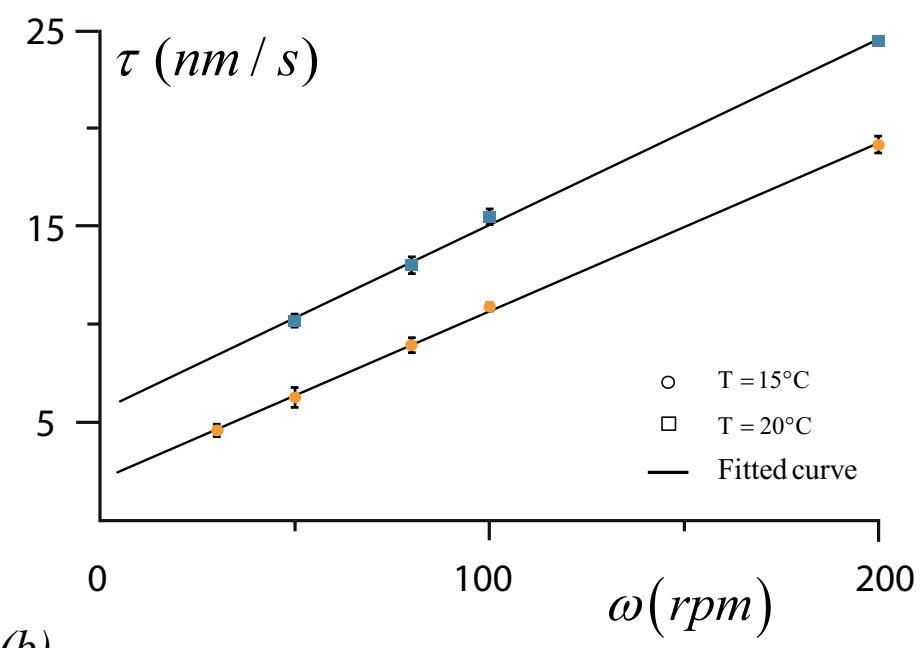

(b)

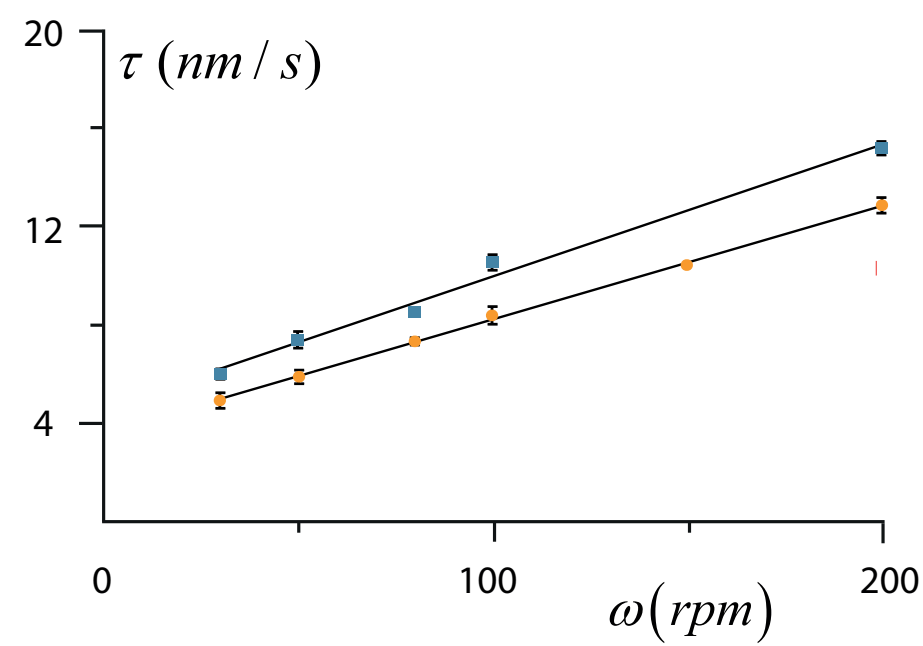

Fig. 7 Experimental recession rates as a function of the rotation speed $\omega$ : a) gypsum alabaster b) sacharoidal. For $\mathrm{T}=15$ and $20^{\circ} \mathrm{C}$. Each curve follows a straight line where the intercept defines the dissolution rate at $\mathrm{C}_{b}=0$ (in section 5.1) 


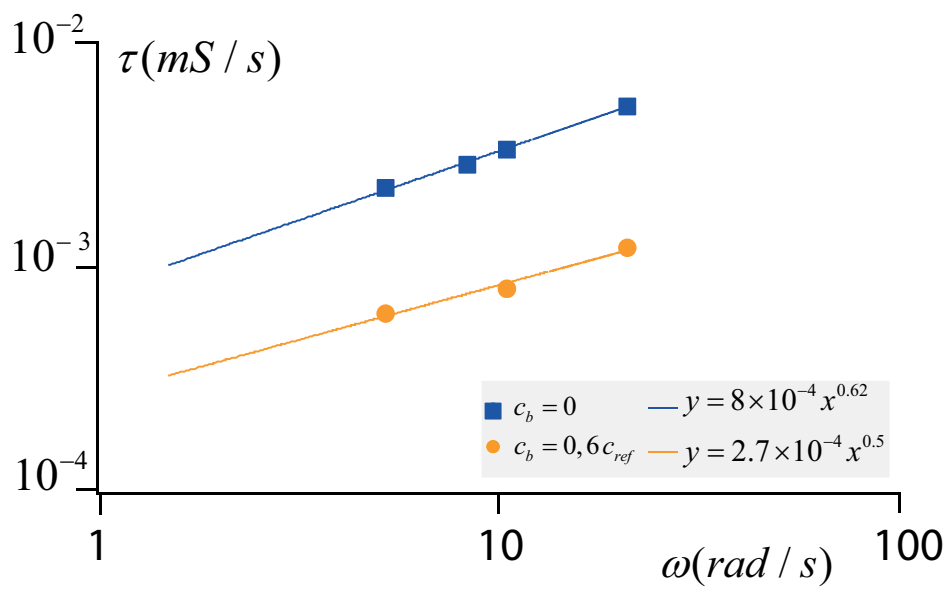

Fig. 8 Dissolution rates by using conventional $\left(\sigma_{\text {start }}=0.6 \sigma_{\text {ref }}\right.$ and $\left.\sigma_{\text {end }}=\sigma_{\text {start }}+10 \mathrm{nS} / \mathrm{cm}\right)$ and unconventional conditions $\left(\sigma_{\text {start }}=0\right.$ and $\left.\sigma_{\text {end }}=\sigma_{\text {ref }}\right)$ for a gypsum alabaster sample at $T=15^{\circ} \mathrm{C}$ (in section 5.1)

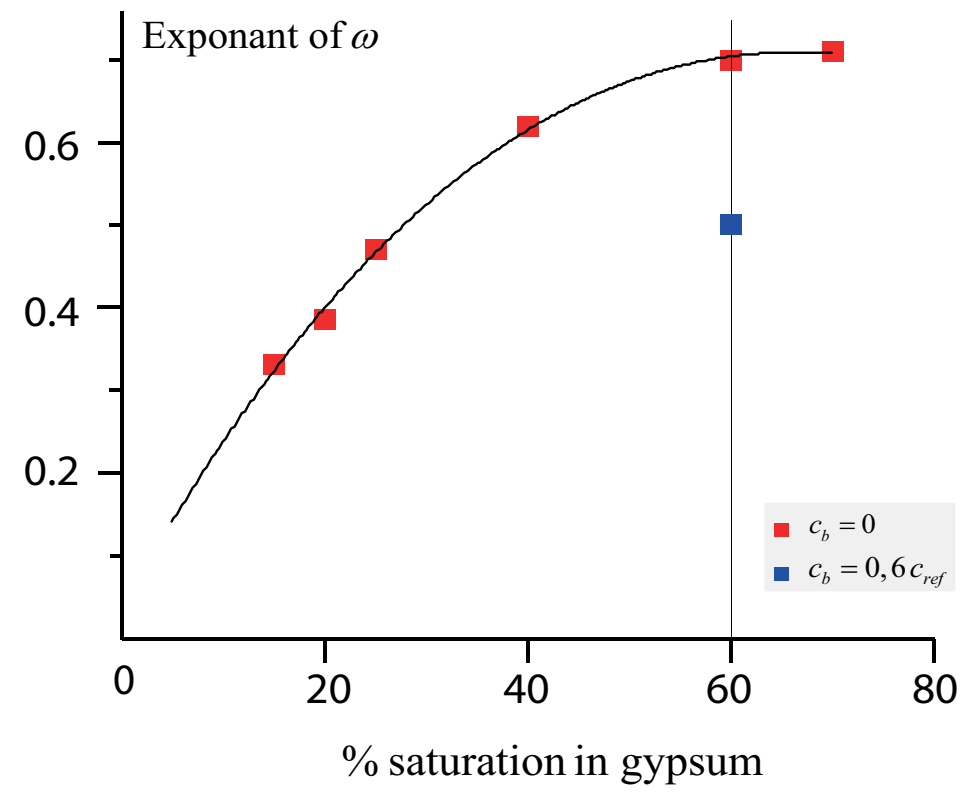

Fig. 9 Evolution of the exponent of $\omega$ along the rotating disk experiment for a matrix textured gypsum sample at $T=20^{\circ} \mathrm{C}$ (in section 5.1) 

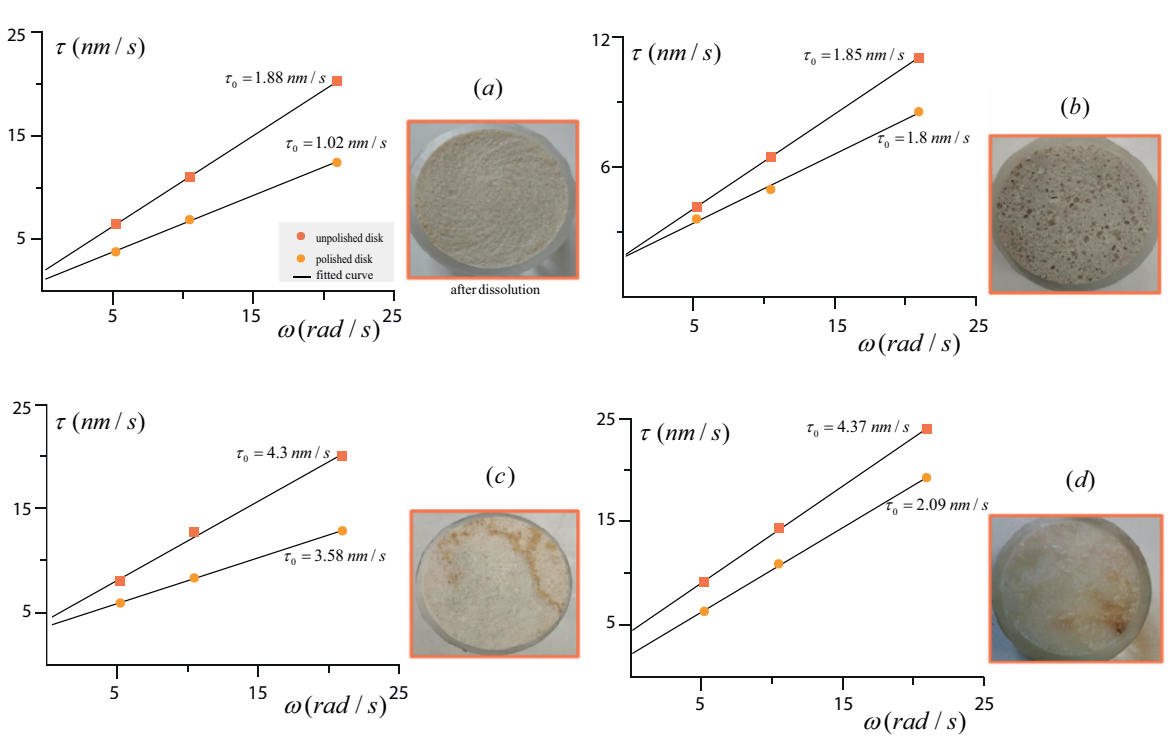

Fig. 10 Evolution of the recession rate as function of the rotation speed $\omega$ by using polished or dissolved disks: a) sacharoidal I b) matrix textured. Heterogeneous textured gypsum: c) alabaster d) sacharoidal II (in section 5.1)

(a)

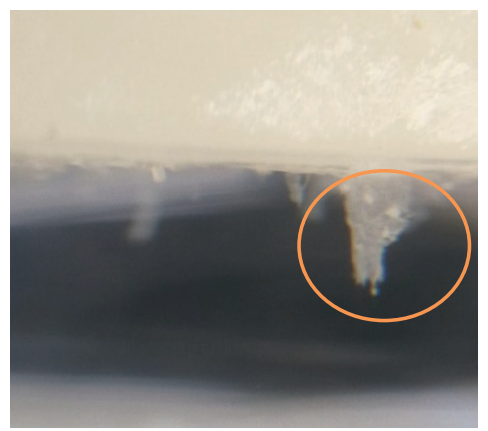

(b)

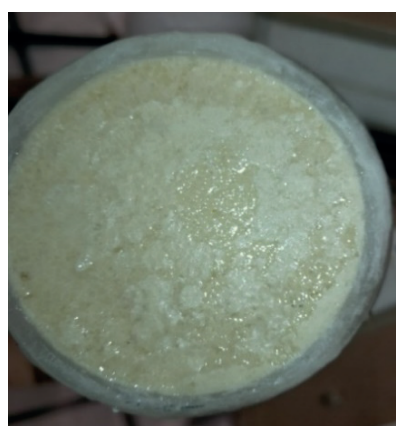

Fig. 11 Observations at the end of a rotating disk experiment: a) millimeter-length dendrite beneath an alabaster gypsum disk, b) gel on the dissolved surface of sacharoidal gypsum disk could represent indices of recrystallization and/or supersaturation (in section 5.2.1) 
(a) alabaster

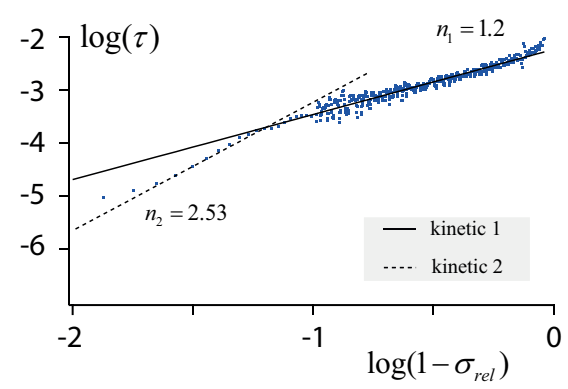

(c) sacharoidal

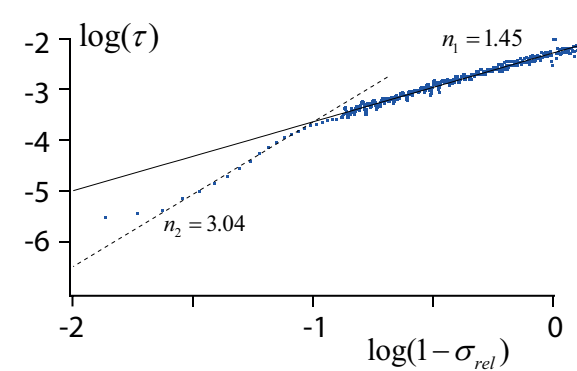

(b) matrix textured gypsum

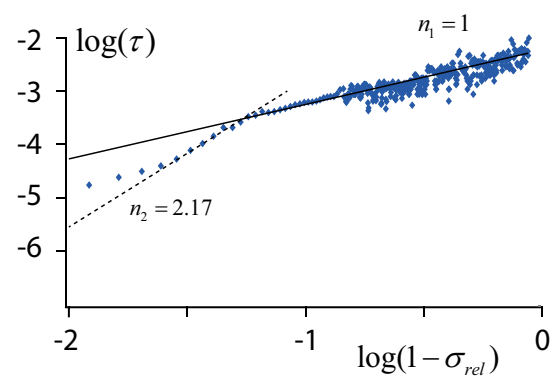

(d) sacharoidal (Gypsum of Vaujours)

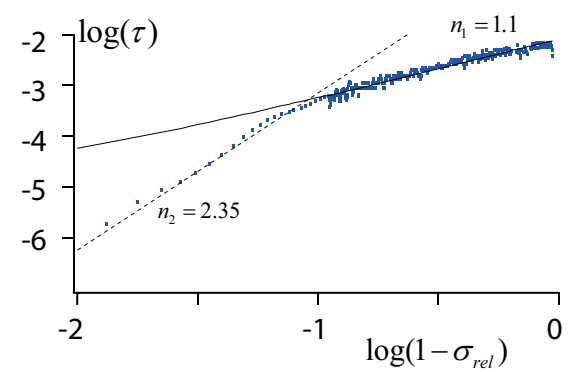

Fig. $12 \mathrm{Log}-\log$ of the dissolution rate as a function of $\left(1-\sigma_{r e l}\right)$ : a) alabaster b) matrix textured gypsum c) sacharoidal I d) sacharoidal II. The straight line presents the fitting of the dissolution kinetics far from equilibrium, the dotted line shows the fitting close to equilibrium with a transition close to $0.94 \sigma_{\text {ref }}$ (in section 5.2.2) 


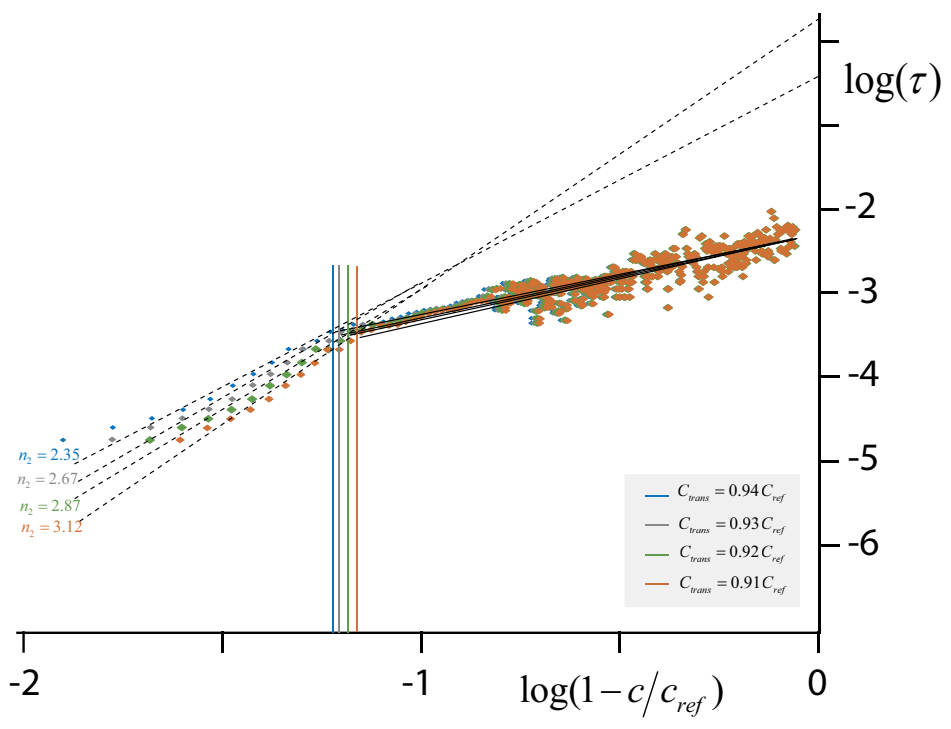

Fig. 13 Behavior of the kinetic law parameters and $\mathrm{C}_{\text {trans }}$ to small variations of $\mathrm{C}_{\text {ref }}$ for the matrix textured gypsum (in section 5.2.2) 